\author{
Anu Lahtinen \\ (D) https://orcid.org/0000-0001-6016-2253 \\ Terhi Katajamäki \\ (D) https://orcid.org/0000-0003-0939-2285
}

\title{
SEALED WITH TEARS: MATERIAL AND SOCIAL MEANINGS OF A ROYAL LETTER BY COUNTESS PALATINE ANNA (VASA) (1545-1610)
}

\section{KEYWORDS}

early modern letter writing; Countess Palatine Anna (Vasa); Ars dictaminis; the Vasa Family; royal correspondence; sixteenth-century Sweden

In the Swedish Royal Archives, there are many letters sent by the five daughters of king Gustav I (Vasa) of Sweden (d. 1560). The daughters were raised to be married away to foreign princely dynasties and in due time, they all fulfilled this expectation. While they lived abroad, they corresponded with their Swedish relatives and in-laws and did their best to promote the interests of their brothers Erik, Johan and Karl, who one by one succeeded to the throne (Rangström 2010:

Anu Lahtinen - Associate Professor of Finnish and Nordic History, Faculty of Arts, P.O. Box 59, FIN-00014 University of Helsinki; e-mail: anu.z.lahtinen@helsinki.fi

Terhi Katajamäki - M.Soc.Sci, M.Ed, PhD Student, Faculty of Arts, FIN-20014 University of Turku; e-mail: tmekat@utu.fi 
122-124; Tegenborg Falkdalen 2010). The correspondence as such as well as the content of the letters reflect the important yet often vulnerable position of consorts living abroad, trying to act as mediators between their family of birth and the family of their in-laws.

Sixteenth-century Swedish letters are often rather formal in style, and many are formulated or written by scribes, which may add to the distance in the tone of the letter as we experience it. However, some exceptional letters stand out in their straightforwardness. One of them, undated but written in 1592, was sent by Anna (1545-1610), the third daughter of Gustav Vasa, to the Queen of Sweden, Gunilla (1568-1597).

The outward appearance of the sealed letter is formal, with the lengthy address written in German and in handwriting, which was typical of texts written in German. According to the address, the letter was to be delivered personally to the "Princess and Lady" Gunilla, who is referred to by her full royal title and described as "Our friendly, whole-heartedly beloved Lady's Sister and Sister-in-law \&c" (Appendix, lines 97: 103-104). The sisterly rhetoric, otherwise unthinkable in a letter addressing a Queen, was justified by the fact that Queen Gunilla, born into the aristocratic Bielke family, was the second wife of Anna's brother King Johan III (1537-1592).

When the letter is opened and the written message is revealed, the reader gets an impression that is rather different from the initial one. The formal handwriting, the use of the pluralis majestatis and decorative style of address give way to a plain, sorrowful account of economic problems, written in Swedish in the sender's own simple handwriting. At the time she wrote the letter, Anna had recently been widowed. In 1562, in her late teens, she had become the spouse of Georg Johann (sometimes referred to as Georg Hans), Count Palatine of Veldenz (Germ. Pfalzgrafvon Pfalz-Veldenz) (1543-1592). Encouraged by the handsome dowry of 100000 thalers (Sw. riksdaler), promised to each of Gustav I's daughters, Georg Johann I became involved in ambitious political projects and power struggles that swallowed up the property of the family. By the time of his demise in April 1592, his little realm was split between his sons and the family was deep in debt. The dowry of the Swedish-born Countess Palatine was never paid in full (Bergstrand 1920: 20; Lahtinen 2009c: 163-164).

Countess Anna's letter lacks a date but was clearly written after Georg Johann I's death, i.e. in April 1592, and before the death of her brother Johan III of Sweden in mid-November 1592. The three-page-long text starts bluntly with a request for help, as Anna needed a sum of 10000 thalers (Sw. riksdaler), part of her dowry and income that had been promised to her by her royal brother. Anna expressed her wish to receive clear confirmation about how, when, and by whom 
the payment of this outstanding sum would be transferred. There was no doubt that the money was urgently needed, and the letter made several references to the pitiful situation of the widow and her "poor children" (Sw. fattige barn). Finally, it ended with an abrupt reference to the sad physical state of the sender herself (see Appendix, lines 83-95):

I entrust y[our] d[earness] and all the Royal House to the God Almighty's graceful care and protection. I cannot now, due to my heart's great sorrow, write more, as my head aches so because of crying.

Y[our] D[earness'] Dear and trustworthy

humble sorrowful sister always, whole-heartedly, as long as I live.

Anna Countess Palatine

Widow, M[anu] P[ropria]

In this article, Countess Palatine Anna's letter is analyzed as a text that opens a discussion on the material and social meanings of the correspondence of a Swedish-born consort who lived far from her country of birth. Our close analysis of the letter draws attention to many meanings embedded in one (any) historical written source. The article is based on our research on the sixteenthcentury aristocratic and royal families and their correspondence in Sweden (Lahtinen 2009c; Katajamäki 2014). The document is studied in the context of early modern correspondence, with special attention to the letter as a physical object that was meant to convey (and conceal) a message, in the actual textual communication and its cover. We discuss both the content and structure of the letter and its physical appearance.

Firstly, we will describe the letter and analyze it in the context of the sixteenthcentury letter writing. Secondly, we will discuss the function of the letter in the social networks of an early modern consort. Finally, we will provide a concluding discussion of the letter in the context of cultural transfer.

\section{The Anatomy of a Sixteenth-Century Royal Letter}

While many surviving Swedish sixteenth-century objects can only be speculatively identified as having belonged to certain individuals at a certain time period, ${ }^{1}$ letters can most often be dated and their senders and addressees identified. Still,

${ }^{1}$ On the problems related to identifying and analyzing Swedish sixteenth-century objects, see, for example, Vilhelm Slomann and the later criticism (Sloman 1934, 1935; Kern, Pezzini 2014). 
several problems of interpretation remain unsolved. Early modern letters are often laden with conventional expressions and may, to a contemporary reader, seem to conceal rather than reveal the aims and feelings of the sender. Moreover, as the early modern letters were often written by scribes or transferred by messengers, the secrecy of correspondence was often not guaranteed. This was why confidential topics were frequently mentioned with caution. As was the case with Anna's letter, senders often referred to further information that would be revealed by word of mouth by a trusted servant or a messenger. In some cases, the letter was merely a physical piece of evidence authorising and legitimising the further information to be related by the messenger (Ward 2001: 32; Lahtinen 2009b).

When it was necessary to transfer confidential information, a literate sender could exclude the scribe from the process by choosing to write a post scriptum or the full letter in his or her own hand. In Swedish aristocratic correspondence, one can sometimes see that the sender has used a scribe for the proper part of the letter and then added a post scriptum on a delicate topic by his or her own hand. ${ }^{2}$ An alternate language could be used in order to conceal the most delicate issues from random readers or spies. ${ }^{3}$ Naturally, in some cases, the choice of writing by one's own hand can be explained in other ways; sometimes, for example, a scribe might simply not have been available. The content of Anna's letter implies, however, an intention to achieve at least some degree of confidentiality. In addition, at least in early sixteenth-century context, writing in one's own hand could be seen as a means of expressing deep respect for the addressee (Nolte 2000: 708-709).

In 1592, right after the Count Palatine's death, the widespread rumours about economic problems or delays in payment could have been harmful to his family members, their credibility and reputation. Writing in her own hand, and writing in Swedish, the widowed consort could hope to conceal at least some unpleasant details from the eyes of unauthorised readers. Since the letter was folded and sealed - the remnants of the seal are still visible - it was safe to give it to another person who would write on it the conventional address with all the necessary royal pomp.

The outer appearance of the letter, with appropriate titles and the use of the pluralis majestatis, presented the relations between the royal sisters-in-law in a way that was proper for anyone to see, while the content of the letter works on a more intimate level. In present day terms, this shows a division between the public and

2 See, for example, letters from Queen (Dowager) Catharina to her sister, Countess Cecilia Stenbock, in Skokloster Collection 2 vol. 5 (Sw. Skoklostersamlingen 2:5), National Archives of Sweden; Countess Palatine Anna (Vasa)'s letter to her former Lady-in-waiting Christina Trolle, with unclear date from the year 1576, vol. X240, Uppsala University Library (Sw. Uppsala Universitets bibliotek).

${ }^{3}$ On a love affair discussed in Italian by two Swedish aristocratic brothers, see Handlingar rörande Skandinaviens historia 7: 68-72; Elgenstierna 1932: 414-412. 
the private; however, this kind of straightforward division was alien to early modern society (Kaartinen 2002: 91-101; Daybell 2012: 24). Still, the outer and inner messages were distinctly different and they were directed to different audiences. The aim of the former was to reflect the position of the consort and the addressee, while the latter put emphasis on the vulnerability of the sender.

The style of the letter is typical of a correspondence between Swedish aristocrats brought up in the mid-sixteenth century. The handwriting (simple, relatively large letters), the way of addressing the addressee, and the structure of the document largely follow the sixteenth-century Swedish conventions. Calling one's sister-in-law "My heart's dear sister" was customary in most social groups where letters were sent at all; only in this case, as the addressee was also the Queen consort of Sweden, there is an additional "lady" in the form of address "My heart's dear lady sister" (Sw. "Min Käre hiertans fru syster") and the sender referred to herself as a "loving" and "humble" sister instead of a more customary "loving and friendly" (Appendix; Lahtinen 2007; Lahtinen 2009b; Koskinen, Lahtinen 2011).

Queen Gunilla was not even born when Anna left Sweden to be married, and the women cannot have had much (if any) face-to-face contact. The rhetoric of friendly and sisterly relations should be understood in the contemporary context, more as a natural state between peers rather than an expression of emotions between bosom friends. Conventional choices of words were not "merely rhetoric"; they could have been used to strengthen, question, or negotiate relations between the sender and the addressee (Koskinen 2005: 239-240).

The relatively straightforward tone in the letter may be due to the age hierarchy that gave Anna more authority. After all, she was a consort in her late forties, born Princess of Sweden, even though the Vasas were an upstart royal family, whose legitimacy rested on the support they received from the most important aristocratic families closest to them. Queen Gunilla Bielke, for her part, was in her midtwenties, the second spouse of elderly King Johan III. Many had considered his second marriage a mésalliance when the wedding took place in 1585, and several of Johan III's siblings had advised or even protested against it (Lager 1967-1969: 419; Rangström 2010: 89-92). While Anna had not been among the most vehement opponents to the marriage, the intimate way in which she addressed Gunilla seems to reflect the fact that Gunilla was, after all, considered more as a personal consolation for the king in his old age than as a dynastic consort, such as his first spouse, Queen Katarzyna Jagiellonka (1526-1582). 


\section{Ars dictaminis}

What serves as a somewhat striking feature of the letter is its very abrupt start. In the sixteenth century, Swedish correspondence still closely followed the medieval rules of ars dictaminis, the art of writing letters. According to the rules, it was important that the style and manner of address reflect the hierarchy between the sender and the addressee. Another important trait was the fixed structure expected of almost any letter. It was supposed to contain the greeting (salutatio), expression of gratitude, and promises to return favours (captatio benevolentiae), the narrative part (narratio), requests for help (petitio), and finally the ending (conclusio) with affirmation of loyalty and friendly greetings to the addressee and those who were close to him/her (Koskinen, Lahtinen 2011; Tiisala 2004: 197-198). What happens in the letter studied here is that the sender misses out the initial steps and proceeds straight to petitio, describing at great length all the fears that she has and referring to the payments that King Johan III has promised (Appendix, lines 1-41):

My heart's dear lady sister, I ask y[our] d[earness] so dearly and humbly [as I fear] that if God finds it good to take me away from this sorrowful world before I get the 10 thousand thalers that his Majesty the King my dear lord brother gracefully has promised to me - Would y[our] d[earness] be so kind and help me get a definite confirmation for the aforementioned amount of money [...] But, alas, his $\mathrm{r}[$ oyal] $\mathrm{m}$ [ajesty] has not given the name of the person [who would provide the sum], therefore I am afraid, my $\mathrm{d}$ [ear] h[eart's] s[ister], as we are all mortal, if God takes me from this world before I receive the money and if, God forbid, something happens to my $\mathrm{d}$ [ear] lord brother, or to $y[$ our] $d$ [earness] then my poor children will not receive anything [...] if I don't get a valid confirmation and verification [...] That is why I beg y[our] $\mathrm{d}$ [earness] so humbly and dearly, that y[our] $\mathrm{d}$ [earness] would offer her help so that I could get the whole amount now, if possible.

The urgency is understandable, given the Countess's dire economic situation. Material worries - and possible distrust of whether the "dear lord brother" would actually be able or willing to fulfill his promises - were toned down and gave way to tender worries over the insecure future and the possible unexpected death of the parties involved. The tone of the letter comes close to what Pierre Bourdieu has, in analyzing premodern cultures of reciprocity, referred to as hidden exploitation and symbolic violence - a rhetoric that resorted to repeated euphemisms of friendship in order to obscure the violent and hierarchical relations and interdependency typical of a society with weak institutional structures (Bourdieu 1977: 191-196).

On the other hand, the tone of the letter can also be interpreted somewhat more positively. The straightforwardness seems to imply that the relations between 
the Queen and her sister-in-law were relatively good and uncomplicated; otherwise a more ceremonious use of ars dictamini and reverence in forms of address would have been expected (Lahtinen 2009a). In the end, the sender apologizes for the "bold" tone of her letter and even asks the addressee to interpret her words for the best (Appendix, lines 68-79):

wherever I can, according to my small capacity, as long as I live, I will be of sisterly, pleasing service to y[our] d[earness], in return I am willing to serve you, whole-hearte$\mathrm{dly}$, and I beg y[our] d[earness] humbly and dearly that y[our] d[earness] would now condone his poor and bold letter of mine and the fact that I trouble y[our] d[earness] so much with my affairs, and that you will interpret my intentions better than I have been able to describe them

Afterwards, she proceeds to the conclusio with all necessary greetings and humble apologies.

The widowed Countess Palatine's style of writing, as well as her choice of words in general, comply with the norms and rules of the early modern period. In other letters written by her, Anna uses a similar rhetoric of friendship and cordial relations rather frequently. Several of her surviving letters are requests on the behalf of her court members or other aristocratic persons close to her. ${ }^{4} \mathrm{~A}$ number of her surviving letters were sent to her maid of honour, Swedish noblewoman Christina Trolle, offering worldly-wise expertise on organizing Christina’s wedding to Åke Johansson Bååt. Some letters were written by her own hand, others were written by a scribe and in German. To the extent the personal tone can be deduced from this correspondence, her choice of words seems to reflect a compassionate and benevolent attitude to things and persons discussed. Anna presented herself as a family-centered person who was interested in her inner circle and its well-being. In general, she very rarely used strong and distinct expressions. ${ }^{5}$

Anna could write in German, too, or at least, she sometimes mixed German and Swedish in her writing. However, her language of choice seems to have been Swedish. The correspondence of the Countess Palatine was written in accordance with the Swedish rules of letter writing. It did not present a timeless Swedish culture of correspondence. Her letter writing and handwriting are similar to those

${ }^{4}$ Duke Charles (Karl) to the Countess Palatine Anna (Vasa), 25 September 1571, Letter Registry of Duke Karl (Sw. Hertig Karls registratur) 1571, fol. 48, National Archives of Sweden; Persson 2014: 355.

${ }_{5}$ For further evidence supporting the analysis presented in this subchapter, see Countess Palatine Anna Vasa's letters to her former Lady-in-waiting Christina Trolle, 21 March 1575, a letter with unclear date from the year 1576, 21 June 1580, vol. X240, Uppsala University Library (Sw. Uppsala Universitets bibliotek). Information about Christina Trolle in Elgenstierna 1934, Trolle family, table 29; Anna to Duke Karl / Karl IX, 24 March 1604, Letters to the King, sixteenth to seventeenth century, Karl IX (Sw. Skrivelser till konungen, 1500-1600 -talet, Karl IX:s tid), vol. M-P, National Archives of Sweden. 
of other royal and aristocratic Swedish women who were brought up in and some time after the mid-sixteenth century. She had also acquired expressions from the environment in which she now lived - such as the occasional use of German language or German-influenced spelling, mentioned above. She was balancing in between correspondence in different languages like many correspondents of the time (Magnusson 2016: 131-155).

\section{Conclusion: Contextualizing the Letter}

In the letter analyzed above, Countess Palatine Anna puts a lot of emphasis on her vulnerable position as a mother who is concerned about her children and their future. The style and language seem to underline the anxiety that she felt after the death of her spouse. This brings us to the more precise function that the letter had.

It was their royal brother King Johan III who was responsible for paying the remaining dowries to his sisters. Yet we learn about the situation from a letter that was written to the king's spouse. Queen Gunilla received the letter because she played a typical role of a royal consort in early modern times: she was a mediator between her spouse and someone who wished to gain access to him through her (Norrhem 2003: 145-147; Lahtinen 2009a: 50-61). In the early 1590s, Johan III was old and sickly and the Queen's responsibility for various matters seems to have increased (Lager 1967-1969: 419; Ericson 2004: 320-323). Thus, in troubled times it was important to have her support before more formal appeals for help could be sent to the king.

The Countess Palatine, for her part, was in a transition phase that was decisive both for her future as well as the future of her children and the whole realm. Although she was capable of taking care of many administrative tasks after her the death of her husband, his demise meant that many old allegiances had to be renegotiated on a more formal or informal level. After the death of her husband, an aristocratic or royal widow had to see to it that old relations were affirmed and she had to deal with the subsequent shift in power balance (Lahtinen 2009a: 62-69). In the words of Cordula Nolte, "family dynamics, as well as personal relations, were shaped by the need to keep and extend power and prestige and to maintain property" (Nolte 2000: 705). The letter to Queen Gunilla can be seen as part of this process of renewing allegiances, and the widowed Countess Palatine's choice of words is also revealing in this sense. Like so many widows of her time, Countess Palatine Anna refers to herself as a sorrowful and vulnerable widow in need of protection. Her "poor" children are presented as being in danger of losing all they were entitled to as heirs of their widowed mother. This was a very typical topos used by widows of different social groups. Widows and orphans were presented 
as helpless and vulnerable, and the King had committed himself to protecting people in a vulnerable position (Lahtinen 2009a: 69-103). The letter by Anna, Countess Palatine, and the contrast in its outer and inner appearance illustrate the in-between position of a consort, who was doing her best to negotiate her way in a foreign country that had become her home, resorting to help from her country of birth. The focus was on transferring the wealth, her allotted share of the family property, to her offspring. Several expressions and strategies of the letter were shared by members of both German and Swedish courts and royal families. It should be borne in mind that the letter, although sent to the Swedish consort from a Swedish-born foreign consort, was also a form of communication between two courts far removed from each other. These courts were vastly different in status, one a kingdom, the other a small territory within the German Empire subject to many political constraints. The outer appearance of the letter showed how the relations between the sender and the addressee were manifested by the Court of Veldenz. It was a message visible to anyone who handled or saw the folded letter.

When it comes to the content of the letter, it gives one an idea of the very complicated situation of a consort suspended in-between two dynasties, as "a stranger within the family" (Nolte 2000: 712). The geographical distance separated her from her family of birth, and in her communication with Sweden, she had to rely on decades-old personal impressions and second-hand information mediated by letters and messengers. The distance in time and space made her, little by little, a stranger to her own family and country. In the situation at hand, the widowed Countess Palatine depended on the help of her family and country of birth, and on the sympathy and reciprocity that she could evoke.

When discussing the correspondence of consorts, it is important to take both its verbal and material aspects into account. The letter conveyed a mixed message of the relative power and powerlessness of a consort. The letter of the widowed Countess Palatine Anna presents a rather dramatic stage in the flow of communication between her and her family and country of birth, conditioned by a longtime transfer of information and influences, Swedish and German.

\section{APPENDIX: A Transcription of the Letter}

Countess Palatine Anna (Vasa) to Queen Gunilla.

Undated, but written between April 1592 - mid-November 1592 (after the death of Georg Johann, before the death of Johan III)

Riksarkivet (National Archives of Sweden), Kungliga Arkiv 73 (Royal Archives vol. 73), Svenska drottningars arkiv (Archive of the Swedish Queens) 
Queen Gunilla Bielke's archives, Incoming letters to Queen Gunilla Bielke characters in \{\} : crossed out by the letter writer characters in []: letters added to a shortened word

\section{Original, Swedish and German text}

\section{page I}

Min käre hiertans fru syster iag beder och e[der] k[ärlighet] så kärlige och ödmiuke lige at åm gud tekes at biude öfwer mich och kalle mich af thenne bedröf

5 wade werden för en iag bekåmer di 10 tussen rigs daller såm kong maiiestat min käre herre bror mich nådigt har tilsagt at $\mathrm{e} \mathrm{k}$ wille görre så wel och hielpe mich at

10 iag på samme summe för måte få en wis och god försekring \{ther på\} huar iag thet wist skal bekå me och hos huem iag thet kan lete herwte fordre at then manen

15 blifue nemd för min käre $\mathrm{h}$ [iertans] f[urstlige] syster mich hertil stor vnko stnet att hertil \{hertil\} har gåt ther på kong Maiiestät min $\mathrm{k}$ herrbror schrifuer wel at iag dem förste iuli

20 alle år skal pensionnen bekåma til thes hans maiiestat er legeli get att betalle helle summen men hans $\mathrm{k}$ [ungliga] $\mathrm{m}$ [aiestet] nemner lel ingen huem thet är så fruchter iag

25 min $\mathrm{k}$ [äre] $\mathrm{h}$ [iertans] s[yster] efter wi ere alle dödelige och gud tager mig hedan fören iag thet bekåmmer och ther gud alsme chtige förbiude at min $\mathrm{k}$ herr bror sedan någet kåmme wed heller

30 e k så skulle minna fatige barn sedan intet bekåme thett och sedan ingen uille weta någet theraf 
iag icke har en god försechring och

35 lege åp så warder mina fatige barn kåmme plat theråm therföre beder iag e k ännu så ödmiukelige och kärlige, e k will ware mich her vti behielpelich at iag doch helle

40 summen nu måte bekåme åm thet wåre mögeligit på thet iag \{kunne\} iag then schwåre pension såm iag alle år herute måte ge til stråsborg kunne lössa huar tet icke

45 nu kann ske på thenne gång at iag då wist måte bli försekret på pensionnen såm för er melt der åm beder iag på tet ödmiukelige och håpes e $\mathrm{k}$ warder her vti göre

50 såm min hiertans gode siisterlige förtrogning til e k står gud alsme chtig han spare kong maiijstat min käre herr bror och e k liffuet och åp ehålle E K M samtlige wed

55 al god liffs helsa, och sunhet både lenge och wel beder iag af alt met hierta så wet iag wel och mina käre barn warde thet well bekåmme, iag håpess och $\mathrm{e} \mathrm{k}$ warder mich icke her

60 vti förthencke att iag nu så miiket manner e $\mathrm{k}$ herupå gud wet åm minna och mina $\mathrm{k}$ barns sacker nu icke stode så beschwerlige wille iag intet så drifue therupå såm nicklas

65 widere e $\mathrm{k}$ wel warder bereta ner gud wil han kåmmer till e $\mathrm{k}$

page III

hure alle saker står wti al then måte wti al then måte iag efter min ringe för mögenhet så lenge iag lefuer åter

70 altid kan ware e $\mathrm{k}$ til al siister lich behaglich tienst igen wil iag 
af alt met hierta så gerna göre och beder e k så ödmiukelige och kärlige e $\mathrm{k}$ wil nu hålle mich

75 thenne min onde och dristige schrifuelse til gode och at iag nu så miiket bemöder e $\mathrm{k}$ med mina saker och thet alt betre förstå en iag har kunnet schrifue och

80 lete sig mich altid uti thet trogna och gode siisterlige hierta altid til thet besta ware befallen hermed befaller iag nu e k samt thet helle kongelige husset vti gus

85 den alsmechtiges nådige beskiid och bescherm iag kan nu för hertans stor bedröwelse icke mere schrifue met hufuet gör mich nu så ont af gråt

90 E K Käre och trogna ödmiuke bedröwade siister altid af hiertat så lenge iag lefuer.

Anna pfaltz grauin

95 witwe MP

page IV

Der Durchleuchtigstes Grossmechtiges

Fürstin vnd Frauwes Frauwen

Gundele Zu Schweden der Gotthens

Vnd wendes \&c. Königin, Grossfürstin

100 in Finlandt; Carele Watzky

Pethin Vnd Jngern in Reusslandt der

Effter in Liflandt Herzogin, vnseren

freundtliches herzliebes Frauwes

Frauwes Schwester vnnd Schwegerin \&c.

105 Zu Ihrer ldch:te

eigenes hendes \&c. 


\section{English translation}

page I

My heart's dear lady sister I

ask y[our] d[earness] so dearly and humbly

that if God finds it good

to take me away from this sorrowful

5 world before I get

the 10 thousand thalers that

his Majesty the King my dear lord brother

gracefully has promised to me - Would y[our] d[earness]

be so kind and help me

10 get a definite confirmation for the

aforementioned amount of money

and where I shall get it

and to whose place I could send an envoy to

collect it, so that the man

15 would be named as, my dear

$\mathrm{h}$ [eart's] $\mathrm{p}$ [rincely] sister, I have been incurred

expenses related to my current circumstances.

His Royal Majesty my d[ear] lord brother

writes indeed that on the 1st of July

20 every year I can get my annuity

until His Majesty is able

to pay the whole amount.

But, alas, his $r[$ oyal] $\mathrm{m}$ [ajesty] has not given

the name of the person, therefore I am afraid,

$25 \mathrm{myd}$ [ear] h[eart's] s[ister], as we are all mortal,

if God takes me from this world before I

receive the money and if, God Almighty

forbid, something happens

to my $\mathrm{d}[$ ear] lord brother or

30 to $y$ [our] $\mathrm{d}$ [earness] then my poor children will not

recive anything and then

nobody will want to know anything about

page II

what $\mathrm{h}$ [is] $\mathrm{r}$ [oyal] $\mathrm{m}$ [ajesty] gracefully has promised, if

I don't get a valid confirmation

35 and verification, then my poor kids may

be left totally without money. That is why

I beg y[our] d[earness] so humbly 
and dearly that y[our] $\mathrm{d}$ [earness] would offer

her help so that I could

40 get the whole amount now,

if possible so that I could

arrange for

the heavy payment that

I must make every year to

Strasbourg. If the whole payment is not

45 possible this time, then I

am asking for a valid confirmation of

the annuity that I have been promised, this

I beg most humbly

and I hope y[our] $\mathrm{d}$ [earness] will act here

50 as my heart's good sisterly

confidence is in y[our] d[earness]. May God

Almighty protect the Royal Majesty my

dear lord brother and y[our] d[earness] and

may he keep Y[our] R[oyal] M[ajesties] both

55 healthy and sound both long

and well. I beg from all my heart

so that I would well know that my dear

children are going to get the payment,

And I hope that y[our] d[earness] will not

60 think badly of me as I now ask

so much from y[our] $\mathrm{d}$ [earness]. God knows if

me and my d[ear] children

had not had such a hard time then I

would not press for this, Niklas

65 can tell y[our] d[earness] more,

when God wills he can come to y[our] d[earness],

page III

what our situation is like.

wherever I can, according to my small

capacity, as long as I live,

$70 \quad$ I will be of sisterly, pleasing

service to y[our] d[earness], in return

I am willing to serve you, whole-heartedly,

and I beg y[our] d[earness] humbly and

dearly that $y$ [our] $\mathrm{d}$ [earness] would now condone

75 this poor and bold

letter of mine and the fact that I

trouble y[our] $\mathrm{d}$ [earness] so much with 
my affairs, and that you will interpret my intentions better than I have been able to describe them and

80 let me always, with my loyal and good sisterly heart, be understood for the best. With these words I entrust y[our] d[earness] and all the Royal House to

85 the God Almighty's graceful care and protection. I cannot now, due to my heart's great sorrow, write more, as my head aches so because of crying.

90 Y[our] D[earness's] Dear and trustworthy humble sorrowful sister always, whole-heartedly as long as I live.

Anna Countess Palatine

95 Widow, M[anu] P[ropria]

\section{page IV}

To the Highly Esteemed Mighty

Princess and Lady, Lady

Gunilla of Sweden, Drottning of Gotes and Vendes, Grand Duchess

100 of Finland, Carelia, Vodskaja pjatina and Ingria in Russia, as well as Duchess of Livonia, our Friendly, whole-heartedly beloved Lady's Sister and Sister-in-law \&c,

105 to Her [...] own hand \&c. 

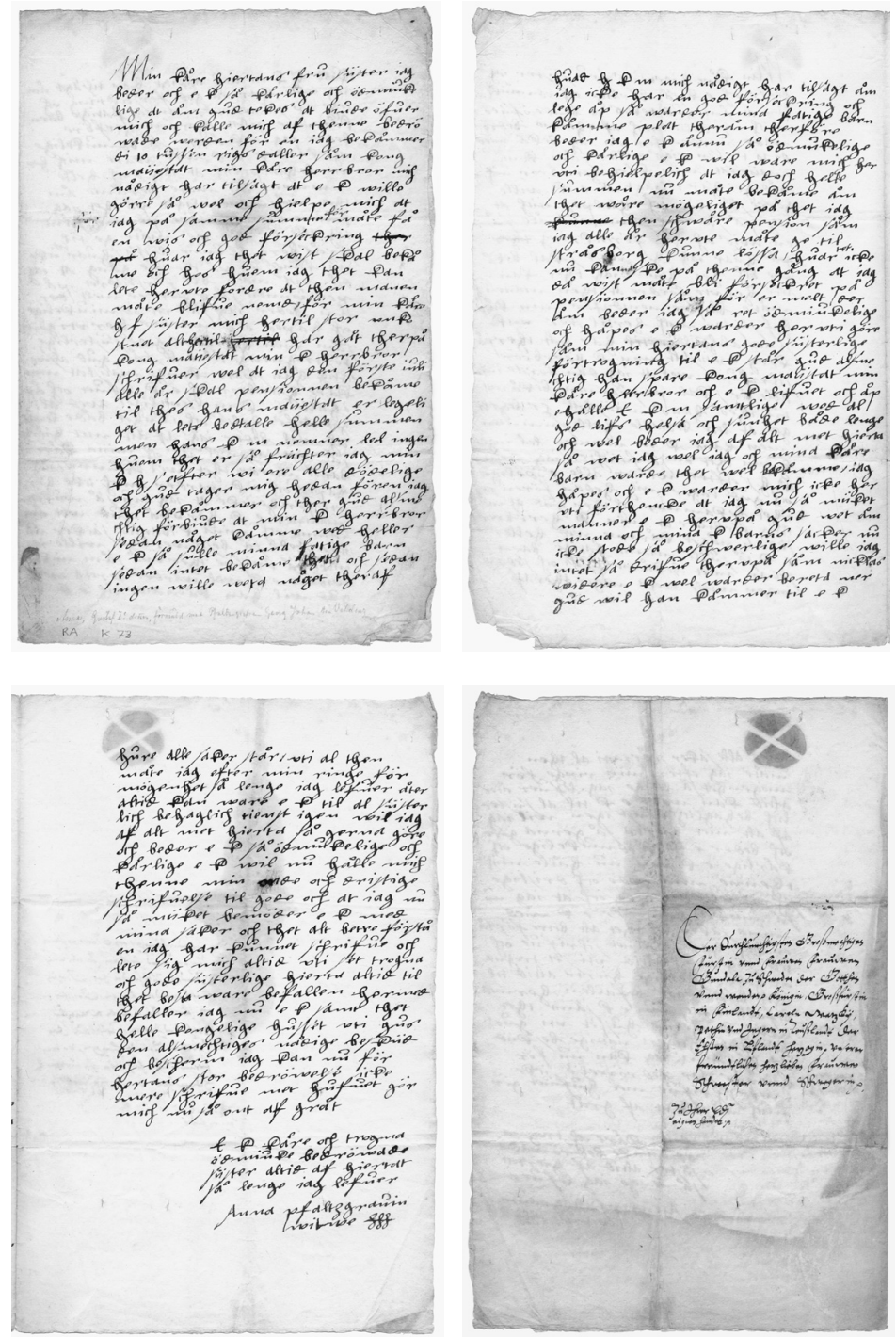

Il. 1-4. The letter, pages I-IV. Riksarkivet (National Archives of Sweden), Kungliga Arkiv 73

(Royal Archives vol. 73), Svenska drottningars arkiv (Archive of the Swedish Queens).

The pictures are from the above-mentioned collection, and they were reproduced by the reproduction services of the National Archives of Sweden, 


\section{BIBLIOGRAPHY}

\section{Archival sources}

\section{Riksarkivet (National Archives of Sweden)}

Hertig Karls registratur (Letter Registry of Duke Karl)

Kungliga Arkiv (Royal Archives) vol. 73

Skoklostersamlingen (Skokloster Collection) 2, vol. 5

Skrivelser till konungen, 1500-1600 -talet, Karl IX:s tid (Letters to the King, sixteenth to seventeenth century, Karl IX)

\section{Uppsala Universitets bibliotek (Uppsala University Library)}

UUB vol. X240

\section{Secondary sources}

Bergstrand Hjalmar. 1920. Anna. In: Svenskt biografiskt lexikon. 2nd ed. Ed. Bertil Boëthius et al. Stockholm: Albert Bonniers boktryckeri. P. 20.

Bourdieu Pierre. 1977. Outline of a Theory of Practice. Cambridge: Cambridge University Press. ISBN: 978-05-1181-250-7.

Dalrymple Roger. 2001. Reaction, Consolation and Redress in the Letters. In: Early Modern Women's Letter Writing, 1450-1700. Ed. James Daybell. Basingstoke-New York: Palgrave. ISBN: 978-02-3059-866-9. Pp. 16-28.

Daybell James. 2001. Introduction. In: Early Modern Women's Letter Writing, 1450-1700. Ed. James Daybell. Basingstoke-New York: Palgrave. ISBN: 978-02-3059-866-9. Pp. 1-15.

Daybell, James. 2012. The Material Letter in Early Modern England. Manuscript Letters and the Culture and Practices of Letter-Writing, 1512-1635. Basingstoke-New York: Palgrave. ISBN: 978-02-3022-269-4.

Elgenstierna Gustaf. 1932. Den introducerade svenska adelns ättartavlor med tillägg och rättelser. VII Schildt-Sture. Stockholm: Kungliga boktryckeriet P.A. Norstedt \& Söners Förlag.

Elgenstierna Gustaf. 1934. Den introducerade svenska adelns ättartavlor med tillägg och rättelser VIII. Stålarm-Voltemat. Stockholm: Kungliga boktryckeriet P.A. Norstedt \& Söners Förlag.

Ericson Lars. 2004. Johan III. En biografi. Lund: Historiska Media. ISBN: 918-50-5747-9. Handlingar rörande Skandinaviens historia 7. 1819. Stockholm: Kungl. Samfundet för utgivande av handskrifter rörande Skandinaviens historia.

Kaartinen Marjo. 2002. Public and Private: Challenges in the Study of Early Modern Women's Lives. In: Time Frames. Negotiating Cultural History. Ed. Anu Korhonen, Kirsi Tuohela. Turku: Kulttuurihistoria, Turun yliopisto. ISBN: 951-29-2238-X. Pp. 89-101. 
Katajamäki Terhi. 2014. Politiikkaa, avioliittoja ja rakkautta. "Hiiskuttua”, no. 1 [online]. https://sites.utu.fi/hiiskuttua/politiikkaa-avioliittoja-ja-rakkautta/ [22.01.2021].

Kern Ulrike, Pezzini Barbara. 2014. Deep Innovation or mere Eccentricity? The Controversial Writings of Vilhelm Slomann (1885-1962) for the Burlington Magazine. “The Burlington Magazine Index Blog” [online] March 2014. https://burlingtonindex. wordpress.com/2014/03/26/vilhelm-slomann-burlington-magazine/ [22.01.2021].

Koskinen Ulla. 2005. Friends and Brothers. Rhetoric of Friendship as a Medium of Power in Late-16th-century Sweden and Finland. "Scandinavian Journal of History", no. 30 (3-4). ISSN: 0346-8755. Pp. 238-248.

Koskinen Ulla, Lahtinen Anu. 2010. Siskot, veljet ja erityisen hyvät ystävät. Aatelismiesten ja -naisten kirjeenvaihto uuden ajan alun Ruotsissa. In: Kirjeet ja historiantutkimus. Ed. Anu Lahtinen, Maarit Leskelä-Kärki, Kirsi Vainio-Korhonen. Helsinki: Suomalaisen Kirjallisuuden Seura. ISBN: 978-95-2222-341-8. Pp. 83-112.

Lager Birgitta. 1967-1969. Gunilla Bielke. In: Svenskt biografiskt lexikon 17. Ed. Erik Grill et al. Stockholm: Kungliga Boktryckeriet P. A. Norstedt \& Söner. P. 419.

Lahtinen Anu. 2007. There's No Friend like a Sister': Sisterly Relations and the Rhetoric of Sisterhood in the Correspondence of the Aristocratic Stenbock Sisters. "COLLeGIUM 2" [online]. http://www.helsinki.fi/collegium/journal/volumes/volume_2/ [22.01.2021]. Pp. 180-203.

Lahtinen Anu. 2009a. Anpassning, förhandling, motstånd. Kvinnliga aktörer i släkten Fleming 1470-1620. Helsingfors-Stockholm: Svenska Litteratursällskapet i Finland - Bokförlaget Atlantis. ISBN: 978-95-1583-178-1.

Lahtinen Anu. 2009b. Kärlek och förpliktelser: aristokratiska systrars brevväxling under 1500-talet. "Folkmålsstudier", no. 47. ISSN: 0356-1771. Pp. 45-66.

Lahtinen Anu. 2009c. Pohjolan prinsessat. Viikinkineidoista renessanssiruhtinattariin. Jyväskylä: Atlantis. ISBN: 978-95-1796-595-8.

Magnusson Lynne. 2016. Mixed Messages and Cicero Effects in the Herrich Family Letters of the Sixteenth Century. In: Cultures of Correspondence in Early Modern Britain. Philadelphia: University of Pennsylvania Press. ISBN: 978-08-1224-825-8. Pp. 131-155.

Nolte Cordula. 2000. Gendering Princely Dynasties: Some Notes on Family Structure, Social Networks, and Communication at the Courts of the Margraves of Brandenburg-Ansbach around 1500. "Gender \& History", no. 12 (3). ISSN: 0953-5233. Pp. 704-721.

Norrhem Svante. 2003. Normbryterska eller ansvarstagande hustru? In: Maktens skiftande skepnader. Studier $i$ makt, legitimitet och inflytande $i$ det tidigmoderna Sverige. Ed. Börje Harnesk. Umeå: Institutionen för historiska studier vid Umeå universitet. ISBN: 917-30547-71. Pp. 141-156.

Persson Fabian. 2014. Living in the House of Power. Women at the Early Modern Swedish Court. In: The Politics of Female Households. Ladies-in-Waiting across Early Modern Europe. Ed. Nadine Akkerman, Birgit Houben. Leiden: Brill. ISBN: 978-90-0425-839-6. Pp. 345-363. 
Rangström Lena. 2010. En brud för kung och fosterland. Kungliga svenska bröllop frän Gustav Vasa till Carl XVI Gustaf. Stockholm: Livrustkammaren and Atlantis. ISBN: 97891-7353-362-1.

Slomann Vilhelm. 1934. The Indian Period of European Furniture I. "The Burlington Magazine for Connoisseurs. Illustrated Published Monthly”, no. 65 (9). Pp. 113-126.

Slomann Vilhelm. 1935. The Indian Period of European Furniture. A Reply to Criticisms. "The Burlington Magazine for Connoisseurs. Illustrated Published Monthly", no. 66 (1). Pp. 21-26.

Tegenborg Falkdalen Karin. 2010. Vasadöttrarna. Lund: Historiska Media. ISBN: 97891-8726-359-0.

Tiisala Seija. 2004. Power and Politeness. Languages and Salutation Formulas in Correspondence between Sweden and the German Hanse. "Journal of Historical Pragmatics", no. 5. ISSN: 1566-5852. Pp. 193-206.

Ward Jennifer C. 2001. Letter-Writing by English Noblewomen in the Early Fifteenth Century. In: Early Modern Women's Letter Writing, 1450-1700. Ed. James Daybell. Basingstoke-New York: Palgrave. ISBN: 978-02-3059-866-9. Pp. 29-41.

Anu Lahtinen

Terhi Katajamäki

\title{
SEALED WITH TEARS: MATERIAL AND SOCIAL MEANINGS OF A ROYAL LETTER BY COUNTESS PALATINE ANNA (VASA) (1545-1610)
}

\author{
(abstract)
}

This article offers a case study of how a royal letter can be studied both from verbal and material perspectives. It examines one such letter and the way it reveals personal intentions, and tensions in family relations. Building on their research on the sixteenth-century Swedish letter writing and the Vasa family, the authors give a detailed analysis of Countess Palatine Anna's (1545-1610) letter from the year 1592, its content and context. The analysis also serves to illustrate the vulnerable position of a consort living far from her family of birth.

SŁOWA KLUCZOWE

korespondencja z czasów wczesnonowożytnych, Anna Wazówna, Ars dictaminis, ród Wazów, korespondencja rodów królewskich, szesnastowieczna Szwecja 